\title{
Inauguration speech
}

\section{October 2015 at the Van Swieten Hall of the Medical University of Vienna}

\author{
Markus Müller
}

Published online: 8 January 2016

(C) Springer-Verlag Wien 2015

Distinguished Guests,

Dear Ladies and Gentlemen,

Dear Colleagues,

Six hundred and fifty years after the founding of the Faculty of Medicine, one of the founding faculties of the University of Vienna, it is my great honor today, also on behalf of my team-Michaela Fritz, Anita Rieder, Volkan Talazoglu, and Oswald Wagner-to take over the chain of the Rector and the scepter of the University from Rector emeritus Wolfgang Schütz, who was the founding rector of the Medical University of Vienna. They are symbols of a special position within a long tradition.

The renovated van Swieten Hall reminds us of the golden age of this tradition, of famous names such as Gerard van Swieten, Karl Rokitansky, Sigmund Freud, Karl Landsteiner-and Gabriele Possanner, who in 1897 was the first woman to be promoted Doctor of Medicine at the University of Vienna. They all cherished the tasks foreseen for the university by Duke Rudolf IV, the Founder. Many of you will recall the memorable lecture given by Prof. Gottfried Schatz on March 12, 2015 to celebrate the 650th anniversary of the University. He emphasized that Universities do not primarily stand for the transfer of knowledge-which can sound rather complacent-but for an attitude. An attitude of humility based on the Socratic principle "I know that I know nothing." But also for a passionate, creative struggle with the unknown or not-yet known. And it is precisely this

Inauguration speech by Rector Univ.-Prof. Dr.med. Markus Müller, 27 October 2015 at the Van Swieten Hall of the Medical University of Vienna, 1090 Vienna.

Univ.-Prof. Dr.med.univ. M. Müller ( $\square)$

Medizinischen Universität Wien,

Spitalgasse 23,

1090 Vienna, Austria

e-mail: markus.mueller@meduniwien.ac.at attitude that has borne rich fruit in recent centuries, also for countless generations of patients. Eric Kandel has given this process a neurobiological basis and noted: "We are who we are because of what we learn and what we remember." This reminds us particularly of the longstanding formative influence of our universities on our students. More important than the transfer of genes are our thoughts and attitudes. "It's not intellect that makes a great scientist," Einstein formulated, "it's character!"

This thinking disappeared in 1938 and I want to commemorate it with an example: Otto Loewi-a jewish Austrian Nobel laureate-was arrested with his two youngest sons on March 12, 1938 and, like another 153 members (77\%) of our faculty, was forced to leave Austria. It is to the particular credit of my predecessor, Wolfgang Schütz, and others of his generation that expelled persons such as Eugene Braunwald, Eric Kandel, and Peter Schur-still active and outstanding scientists-are again on friendly terms with our university or, like Karl Djerassi, were cordially connected with the university until the end of their lives.

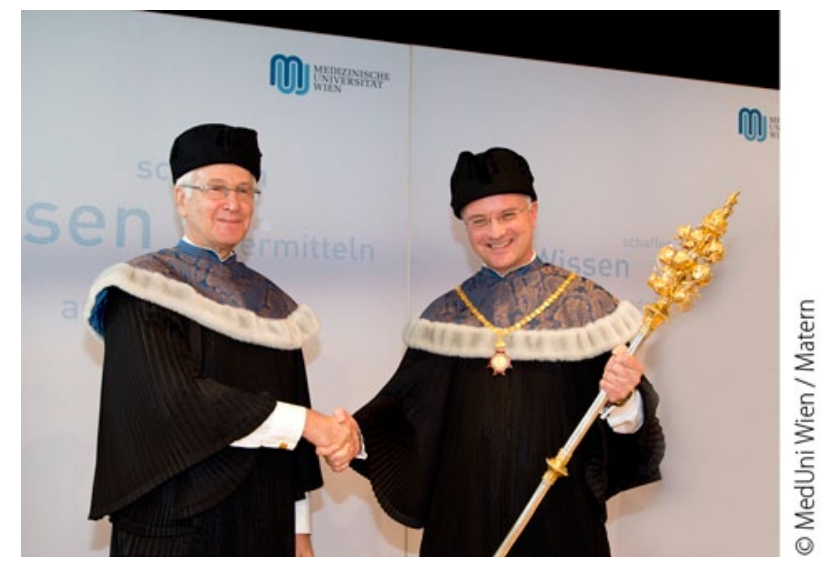


Today people often ask why there are no Nobel Prize winners or Nobel laureates among our scientists, but it was not until many decades after World War II that the University of Vienna managed to regain its standing in international academic medicine.

This dynamic began at about the time that we moved into and started our work at the new General Hospital (AKH). It has been reinforced by the autonomy of the university and the cooperation with our partner universities in Vienna, as well as with the newly established life-science institutions, such as the Research Institute of Molecular Pathology (IMP), and the institutions of the Austrian Academy of Sciences, the Research Center for Molecular Medicine (CeMM), and the Institute of Molecular Biotechnology (IMBA). The Medical University of Vienna complex, together with the AKH, is today again an internationally respected, important center of healthcare, and by far the largest medical training and research institution in Austria. The magnificent, highly complex and interactive services that are provided daily by our colleagues and their teams are also attested by the Medical University's position among the top 100 medical schools in the world. As the only listed Austrian institution, we are among the world's top 50 in the prestigious THE ranking and in the top 20 medical schools in Europe.

Where do we go from here?

Konrad Paul Liessmann has argued that the concept of our time is ephemerality, and he is probably right. We have the feeling that very little of what we currently achieve will endure. We are in an incredible global qualification competition that becomes evident when leaving the borders of Austria, physically or mentally.

Since about 2010, we have been living in a "postLehman World" in Europe, with economic stagnation, consistently high government consumption, and high government debt. In Austria, this has led to decreasing competitiveness and lack of focus on investment for the future-ironically, in contrast to the farsighted vision of the young Duke Rudolf IV.

I would like to draw your attention to some points:

- According to an American study, Research \& Development expenditures in Asia have been increasing continuously in recent years and are currently at $39 \%$ of total world spending. European expenditures are shrinking and are currently at $22 \%$.

- In this context it appears to be no coincidence that the world's largest center for genome sequencing-a technology which is also crucial for the implementation of personalized medicine-is the BGI, founded in 1999 in Beijing.

- However, it is somewhat irritating that in this very hall exactly a week ago, our guest, the Nobel laureate Philip Sharp of MIT, famous for the important discovery of the mechanism of "gene-splicing," informed us that after his arrival at Vienna airport he was welcomed by a poster with the inscription "Austria is gene free."
My experience with other countries is that "the new or foreign," or a word that starts with "atomic" or "gene," is identified as an opportunity rather than a threat.

- When asked "Will science, research and technological innovation have a positive impact on essential issues of life and for the community?" only $35 \%$ of Austrians respond "Yes," according to the current Euro Barometer. Thus, in this attitude, Austria trails far behind the last place of all $28 \mathrm{EU}$ countries.

- This public and hence political position is probably also the reason that the financial strength of Austrian basic research is less than half that of the "innovation leaders," which include comparable countries such as Sweden and Switzerland. Sweden has, for example, only half as many hospital beds per capita but generates twice as many patents.

- I do not know if it is known to you that the annual budget of the University of Stanford is higher than that of all Austrian universities put together or that Harvard Medical School, one of the largest in the world and with a bigger faculty, educates 10 times fewer medical students than the Medical University of Vienna.

In addition, these important points for us as a university also show that, for our daily work with patients, Austrian governance of healthcare is important but unfortunately traditionally inefficient, increasingly manifesting signs of instability.

- In European comparison, we are among the leaders in healthcare by spending $11 \%$ of the national GDP but we are far below the EU28 average in outcome figures, such as those for adolescent smokers or number of healthy life years.

- Half of all those who complete their medical studies here do not want to work in Austria, because of structural deficits, the result of the decades-long policy of "glut of doctors." So we currently find ourselves in a critical phase of development and are sailing in stormy and uncomfortable waters, nationally and internationally. Our slogan must be "Think globally, act locally" within the limits of our radius of operation, and we should borrow a mission statement from General Hannibal: "Either we will find a way or we will build one," he reportedly said.

The local challenges of our university are now well known and have been extensively discussed in public. We are currently facing drastic changes in working hours for physicians, and difficult negotiations on the financial, structural, and infrastructural framework for the Medical University of Vienna complex, with the time horizon 2030. In the past few months we have submitted to our contractors concrete and urgently needed concepts for development of our campus. These include the establishment of centers for clinical research, translational medicine, and genome-based personalized medicine at the campus of the General Hospital, as well as a new pre- 
clinical campus to be located at Mariannengasse-Spitalgasse. In addition, joint management of the General Hospital by the rector's office and the office of Vienna's Hospital Compound (Wiener Krankenanstaltenverbund $\mathrm{KAV}$ ) is-amazingly, for the first time in the history of these institutions-close to formal implementation.

In the next few months the results of these negotiations will show whether we are able to continue the dynamics of the past 20 years or whether we will be overtaken by other more competitive institutions.

International competition, which we face every day, is so demanding because there has never been a more exciting time in medicine and the best minds will choose the most interesting locations and the most creative sites. We have to do everything possible-in the global competition for visibility and "best minds" - to provide enhanced internationally perceived and accepted standards.

At medical universities in Europe these standards include, in particular:

1. Financial strength and infrastructure

2. Number of ERC laureates

3. Female quota and quota of international appointments

4. Attractiveness of the curriculum

5. Medical expertise, based on transparent "outcome" parameters

6. General attractiveness of the location
All efforts by the Medical University of Vienna must therefore aim to achieve measurable improvements in these categories.

We are currently experiencing an unexpected revolution in medical research. Sequencing of a single genome in the framework of the HUGO project, which was completed in 2001, cost three billion US dollars-it costs only a few hundred euros today. This megatrend and many others, such as stem cell research or modern methods in medical technology, have a phase of data-driven "postgenomic medicine," blurring the boundaries between biology and technology and between the computer model and reality. To belong on the front line we have to be very pro-active, not reactive. Openness to new or foreign ideas, and willingness to change-the core competencies that the founder Duke Rudolf imagined for the universities-are therefore increasingly a prerequisite for success. If we all are ready for this we will be internationally competitive.

The rectorate team inaugurated today is ready to meet the challenges raised and will do everything possible to further develop the Medical University of Vienna as a pacesetter for Austria's medicine and as a leading international center.

I ask you all for your support and thank you for your attention. 